\begin{tabular}{|c|c|}
\hline 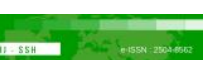 & Malaysian Journal of Social Sciences and Humanities (MJSSH) \\
\hline Malaysian Journal of & Volume 6, Issue 7, July 2021 \\
\hline (MJ-sSH) & e-ISSN : 2504-8562 \\
\hline & $\begin{array}{l}\text { Journal home page: } \\
\text { www.msocialsciences.com }\end{array}$ \\
\hline
\end{tabular}

\title{
Leadership Competencies Development Among Academic Staffs: A Preliminary Observation
}

\author{
Noorasyikin Binti Nordin 1 \\ ${ }^{1}$ Faculty of Management and Economics, Universiti Pendidikan Sultan Idris (UPSI), Malaysia \\ Correspondence: Noorasyikin Binti Nordin (ammardanish09@gmail.com)
}

\begin{abstract}
Every organization needs a leader who is competent in managing change to meet the current demands of remaining competitive in the market, policy demands in government policy, information technology that is evolving day by day. Development of the global technologies required leadership competencies in order to achieve the organizational goal within the current trend setting. Hence, leadership competency development is embracing from time to time to fulfil the organization need not only in technology sector but also to cater the employee's requirement such as skills, knowledges and abilities as well. Competent leaders manage to drive the employees towards the organization objective. They play their roles bringing the employees to work towards the strategic planning that have been plan ahead. This is essential because leader who perform well delegating task and to motivates employees to excellence and in the same time avoid conflict can easily adapt and participate in multicultural teams. This paper investigates the characteristics of leadership development programme that suit for the future leader among academic staffs.
\end{abstract}

Keywords: leadership competencies, leadership development, leadership development programme, development programme, academic staffs

\section{Introduction}

Conflict by conflict arises due to the pressure of the current situation such as politics, economy, social and technology that urges the need of an organization to change from conventional management to information technology management which is felt to be very relevant to the current situation to produce excellent services and improve public knowledge in general (Khair, 2009). To ensure the demands for change in an organization, leaders must play an important role in ensuring that the changes brought later will be well received and accepted by the people of the organization. Skills in changing the attitude of the people of the organization are very emphasized so that the people of the organization can change their perception of change and then accept with an open heart about the changes that will be implemented.

As a competent leader, influencing skill is needed especially dealing with employees in the organization. According to Bennis and Thomas (2002) "influencing ability referring to social skills as ability to engage others in shared meaning and express oneself with a distinctive and compelling voice". Moreover, increased competition both local and global forcing the organization to be more adaptable and deliver quality products and services in a timely manner. Hence a competent leader is needed to perform those 
tasks because with the experiences and also skills they manage to encounter problem or any conflict arise within the organization.

Currently incompetent leadership identified within the organization. Those leaders who lack of leadership course will have problem to delegate task to the subordinates. Delegates are enablers in the organization, but managers are still struggling with how to use them it is effective to get the maximum value. There are many definitions of representation and what is trying to achieve; at its heart, representation is about empowering and authority to perform assigned tasks. This has to do with how power should be handed over so that the given task can be completed successfully. Delegation is not about ordering and expecting everyone to comply but a a two-way process that requires careful thought to succeed. Because it depends on people, care needs to be taken to understand their views to get a purchase. If well managed, able to increase efficiency and productivity in the workplace, increased staff retention, better relationships and trust among employees. On the other hand, if handled badly, it can lead to low staff spirit, poor performance and not delivery (Cooper, 2013).

In addition, leaders who are not knowledgeable in directing task will have problem to direct task to the employees. This may contribute to incompetence leaders in the organization as well. The leaders must be able to think and act in terms of the total system of operation. This includes defining and assigning priorities, planning and organizing, programming and coordinating the operation tasks of a department so that the objective of both the department and the organization as a whole are achieved. This is important because as a leader must excel in interpersonal skills. Handling a variety types of subordinates has become extremely difficult and may contributes to work pressure and also conflict. Hence, deliver information are made through the team with the leader playing the role as the team leader. Once achieving results, delivery information and performance is the key point why the teams exist, and must be part of the team and values every one of them through small celebration. It is clear that successful team very clear, workable towards their goal. This must be done through assessment, flexibility, communication, continuous improvement, high standards, leadership and maximizing the use of available resources (Evenden \& Anderson, 1992).

Leaders who are not skilled also seen as incompetent because lack of attending the leadership course. Leadership training programs can help teach the leaders the essential skills and techniques needed in order to look at challenges from a different perspective. Doing so can add clarity to a difficult situation, and also promotes wisdom and facilitates self-confidence. Leadership training courses use various techniques and examples to emphasize the point that with a little hard work to have it to be great leaders. Part of leadership training is about teaching participants the power to influence those around them. They uncover the elements of motivation and show you how to motivate your team. They also help you discriminate between good and bad sources of power, and between strong and weak methods of influence.

In this inquiry researcher try to explore the current leadership competencies in order to strengthen the delivery information from the leaders towards the employees. This is essential because organisations need to understand the importance of information literacy in the workplace. Knowledge workers are at the centre of business strategy because of their critical thinking abilities and effective communication (Klusek \& Bornstein, 2006). Due to changes in the work environment from routine and repetitive tasks to dynamic activities, it requires advanced communication. Work complexity equally increases communication complexity, sophistication, and processes. In turn, information availability affects decision making and thus work quality. Both delegator and delegate directly affect information quality while communication and direction shapes delegation and thus quality and outcomes (Anthony \& Vidal, 2010).

\section{Literature Review}

\section{Leadership Development}


According to Day (2000) leadership development focusing on the development of individual (leaders) as compared to the development of social structures and processes. He added leadership development focuses on the development of individual leaders while leadership development focuses on development processes that naturally involve a variety of individuals (e.g., leaders and followers or between peers in a self-managed work team).

Looking the development of leadership as the development of the collective capacity to produce direction, alignment, and commitment require a way of understanding an important leadership component that is a way out of how leadership the field has traditionally looked at these components (Drath et al., 2008). Traditionally leadership has been seen as a process of leaders influencing followers against shared goals. Here we see leadership as a process of producing direction, alignment, and commitment in the collective. This view expands the basics understanding of leadership rather than looking at leadership as a specific process (leader influencing followers towards a common goal) to understand leadership as any processes that produce direction, alignment and commitment collectively. This also reflects a broader understanding who produces leadership: from understanding leadership as produced solely by individuals recognized as leaders to understand leadership as produced by the whole collective.

Leader development, the usual emphasis is on the individual knowledge, skills, and abilities related to formal leadership. Ability acquired from people who think and act in new ways (Coleman, 1988). In this way, the main expansion especially functions in human capital. Emphasis on key comprehensive development strategies is for intrapersonal efficiency decisions needed to form precise models' self (Gardner, 1993, p. 9), to engage in the development of a healthy attitude and identity (Hall \& Seibert, 1992), and use the self-model to demonstrate effective performance in any number of organizations. The main emphasis in leadership development is building and using interpersonal competencies. Gardner (1993) defines interpersonal intelligence in terms of ability to understand people basic attention in building trust, respect, and finally commitment.

Leadership development becomes a necessity and a strategy for organizations within the current business environment. Recent historical events and emerging trends are needed to invest in the development of active leaders. Some of the fact that executives are increasingly needed to pay attention to the matter in question initiatives, only a small number are actively developing organizations as part of their own strategy.

This finding is clear in a study that found that almost everyone organizations surveyed indicated a need for leader development, only 44 percent actually a formal process for the process (Giber et al. 2000). As a result, this organizations may not be prepared enough to compete in ever-changing change business methods. It is proven that the organization with a passion for developing the right leaders, appropriate organizational structure and culture, and strategic plans to implement leadership programs will be better prepared for future challenges (Fulmer, 1997; Miller et al., 2001).

Leadership development activities and their effectiveness have not been thoroughly explored in various changes global university settings. As a Higher Education setting radically changed around the world, Higher Education professionals operate in a more uncertain environment, and leaders are increasingly complex and diverse approaches to their leadership roles. Leadership development activities therefore it becomes important in supporting this complex context, yet little is known in the literature about leadership development and its effects in Higher Education. We study peers review leadership development work in Higher Education settings globally to understand what can be learned about its content, processes, results and effects.

\section{Leadership Competencies}

Leadership is crucial to the direction of the organization (Mohd. Yatim 2006; Bush 2008). Leaders play a role as a mentor and motivator to his staff for achieving organizational goals (Mohd Yatim 2006; Bush 2008). To perform the task effectively, leaders need to have the skills and personality quality in addition 
to knowledge in his field (Male 2006). Eddy's (2013) study shows, only only competent leaders can achieve satisfactory results through his leadership.

Organizations that have effective leadership have clear goals, while the organization have ineffective leadership have vague goals (Robinson 2006; Robinson et al. 2008). Only organizations have that goal it is clear only that it can stimulate and move its staff to contribute towards the achievement of the organization brilliant (Robinson 2006; Bush 2008; Robinson et al. 2008). McNair, Duree and Ebbers (2011) in their study found that education leaders need to have skills and competencies to meet challenges lead and manage current institutions. Eddy (2013) in his study found leadership competencies can be developed through training, knowledge acquisition knowledge and experience throughout the service at organization. According to Howson (2005), the problem of appointment the leader of this 21st century is the lack of a candidate capable and qualified. Election of leaders should be based on established competencies organizations (Hollenbeck et al. 2006; Rothwell 2010); to ensure that only the competent are appointed as leader.

Figure 1: Conceptual Framework for Leadership Competencies Development

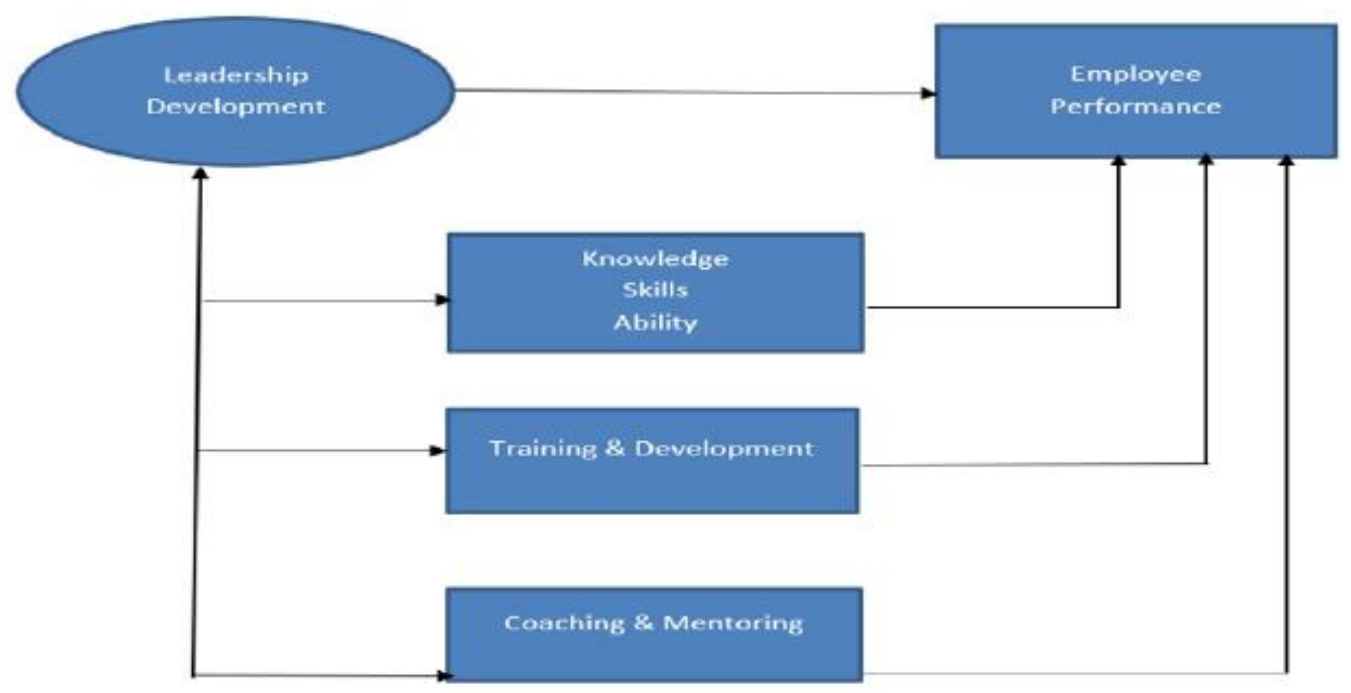

A study conducted by Spendlove (2007) in The United Kingdom found leadership competencies in higher education institutions (HEI) are not the same with leadership competencies in schools. HEI leaders requires some additional competencies compared leadership from different contexts (Spendlove 2007). A review of the literature conducted found not much a study on leadership competencies in Malaysia.

Competence is a necessary characteristic for do something (Chen \& Naquin 2006; Bass \& Bass 2008). Chen and Naquin (2006) define competence as a basic characteristic of the individual required to perform a job for example, skills, knowledge, attitudes, beliefs, motives, and attributes; which enables the production of excellent work in line with the strategic function of the organization. The leader effective are competent leaders (Hollenback et al. 2006; Bass \& Bass 2008; Rothwell 2010). Competencies need to be identified as they are key foundations for effective management (Rothwell 2010). Therefore, to ensure organizational excellence, it is important that competent leaders be appointed to lead the organization (Hollenback et al. 2006; Rothwell 2010).

Howson (2005) in his study of appointment of leaders at ten universities in England and Wales found, most universities such does not have a systematic method for identify potential leaders or provide leader development programs. Study of higher education institutions (HEI) in the United Kingdom shows, as many as $70 \%$ of such educational institutions does not have a leadership development program systematic (Spendlove 2007). In Malaysia, however, the study of Norzaini et al. (2012) found new Higher Education Instituitions does not have a specific development program for academic leaders. 
These studies explained that the appointment of most leaders of educational institutions is without going through specialized leadership development programs. Implications not following a leadership development program is appointed leaders have knowledge or limited ability to manage its institutions effectively (Eddy 2013; Gentry et al. 2013).

\section{Conclusion}

Management support is also one of the important aspects to ensure development academic staffs professionalism on an ongoing basis. The administrators are potential people for managing academic staffs professional development programs on an ongoing basis, being a facilitator to his academic staffs as well as being the resource coordinator for his institution. The success of a program the development of such professionalism competencies depends on the administrator being willing to stimulate and encourage the professional development of his academic staffs.

Goals and objectives of the professional development program that can impact positively must be tailored to the professional needs of the academic staffs. Effective development programs require the needs of the target group to be identified regularly as it will be the foundation for the setting of the program, objectives and activities.

Academic staffs regardless of their level of leadership become role models for their institutions and seem to make it a priority to represent their institutions in a good way. Academic staffs are often seen as highly dedicated to the work they do and making meaningful relationships with others within the institution, as well as serving as an important liaison with stakeholders providing support to their respective institutions to ensure its legitimacy. Thus, it seems that preparation for professionalism is very important for academic staff and they seem to understand the importance of building positive relationships with their constituents and other agencies as well, which interact with the institution.

\section{References}

Anthony, M., \& Vidal, K. (2010). Mindful communication: A novel approach to improving delegation and increasing patient safety. Online Journal of issues in nursing, 15(2), 1-10.

Bass, B. M. \& Bass, R. 2008. The Bass Handbook of Leadership: Theory, Research and Managerial Applications. Edisi ke-4. New York: Free Press.

Bass \& Riggio. (2006). Transformational leadership. (2nd ed.). New Jersey: Lawrence Erlbaum Associates

Bennis, W.G. and Thomas, R.J. (2002). Crucibles of leadership. Harvard Business Review, 80(9), 3945.

Chen, H.-C. (2006). Assessment center: A critical mechanism for assessing HRD effectiveness and accountability. Advances in Developing Human Resources, 8(2), 247-264.

Coleman, J. S. (1988). Social capital in the creation of human capital. American Journal of Sociology, 94, S95-S120.

Cooper, L. (2013). A beginner's guide to effective delegation. Veterinary Nursing Journal, 28(4), 136137.

Day, D. V. (2000). Leadership development: A review in context. Leadership Quarterly, 11(4), 581613

Drath, W. H., McCauley, C. D., Palus, C. J., Van Velsor, E., O’Connor, P. M. G., McGuire, J. B. (2008). Direction, alignment, commitment: Toward a more integrative ontology of leadership. Leadership Quarterly, 19(6), 635-653.

Eddy, P.L. 2013. Developing leaders: The role of competencies in rural community colleges. Community College Review, 41(1), 20-43.

Evenden, R., \& Anderson, G. (1992). Making the most of people. Cambridge: Addison-Wesley Publishers Ltd.

Fulmer, R. (1997). The evolving paradigm of leadership development. Organizational Dynamics, 25(4), 59-72. 
Gardner, H. (1993). Multiple intelligences: The theory in practice. New York: Basic Books.

Giber, D., Carter, L. and Goldsmith, M. (2000). Linkage Inc.'s Best Practices In Leadership Development Handbook, Jossey-Bass/Pfeiffer, San Francisco, CA.

Hall, D. T., \& Seibert, K. W. (1992). Strategic management development: Linking organizational strategy, succession planning, and managerial learning. In D. H. Montross \& C. J. Shinkman (Eds.), Career development: Theory and practice (pp. 255-275). Springfield, IL: Charles C. Thomas.

Hollenbeck, G.P., McCall, W.M. Jr. \& Silzer, R.F. 2006. Leadership competency models. The Leadership Quarterly 17(4): 398-413.

Howson, J. (2005). The State of the Labour Market for Senior Staff in Schools in England and Wales 2004-2005. Available at: http://www.educationdatasurveys. org.uk/NAHT-SHA2005.pdf. Accessed 21 April 2006.

Khair Mohamad Yusuf. (2009). Technology-abled innovations for future educational leaders, administrations and managers dalam Proceeding 1st Regional Conference on Educational Leadership and Management, 29-37. Institut Aminuddin Baki: Kementerian Pelajaran Malaysia.

Klusek, L., \& Bornstein, J. (2006). Information literacy skills for business careers. Journal of Business \& Finance Librarianship, 11(4), 3-21.

Male, T. (2006). Being an Effective Head Teacher. London: Paul Chapman Publishing.

McCall, M.W. Jr and Hollenbeck, G.P. (2002), Developing Global Executives: The Lessons of International Experience, Harvard Business School Press, Boston, MA.

McNair, D.E., Duree, C.A. \& Ebbers, L. (2011). If I knew then what I know now: Using the leadership competencies developed by the American Association of Community Colleges to prepare community college presidents. Community College Review, 9(1): 3-25.

Miller, L., Caldwell, K. and Lawson, L.C. (2001). The leadership investment: how the world's best organizations gain strategic advantage through leadership development. HR Magazine, 46(2), 152-3.

Mohd Yatim Nawai. 2006. Implementasi pengurusan perubahan: Kajian tinjauan di pengurusan Majlis Amanah Rakyat (MARA). Tesis PhD. tidak terbit. Universiti Kebangsaan Malaysia.

Moran, R.T. and Riesenberger, J.R. (1994), The Global Challenge: Building the New Worldwide Enterprise, McGraw-Hill Book Company, London.

Naquin, S., \& Chen, H.-C. (2006). Construct validation of the Louisiana Managerial/Supervisory Survey. In F. M. Nafukho \& H.-C. Chen (Eds.), Academy of Human Resource Development Conference Proceedings (pp. 1400-1407). Bowling Green, OH: Academy of Human Resource Development.

Norzaini Azman, Faizah Abd. Majid \& Noor Hazlina Ahmad. (2012). A conceptualization of succession planning provisions. Dlm. Succession Planning Practices in Malaysian Public

Robinson, V.M.J., Lloyd, C.A. \& Rowe, K.J. (2008). The impact of leadership on student outcomes: An analysis of the differential effects of leadership types. Educational Administration Quarterly, 44(5), 635-674.

Robinson, V.M.J. (2006). Putting education back into educational leadership. Leading \& Managing, 12(1), 62-75.

Rothwell, W.J. (2010). Effective Succession Planning: Ensuring Leadership Continuity and Building Talent from Within. Edisi ke-4. New York: American Management Association.

Spendlove, M. (2007). Competencies for effective leadership in higher education. International Journal of Educational Management, 21(5), 407-417. 